\title{
All roads lead to The New Food Activism
}

Review by Mustafa Hasanov*

Review of The New Food Activism: Opposition, Cooperation, and Collective Action, edited by Alison Hope Alkon and Julie Guthman. (2017). Oakland: University of California Press. Available as hardcover, paperback, and ebook; 344 pages. Publisher's website: https://www.ucpress.edu/book/9780520292147/the-new-food-activism

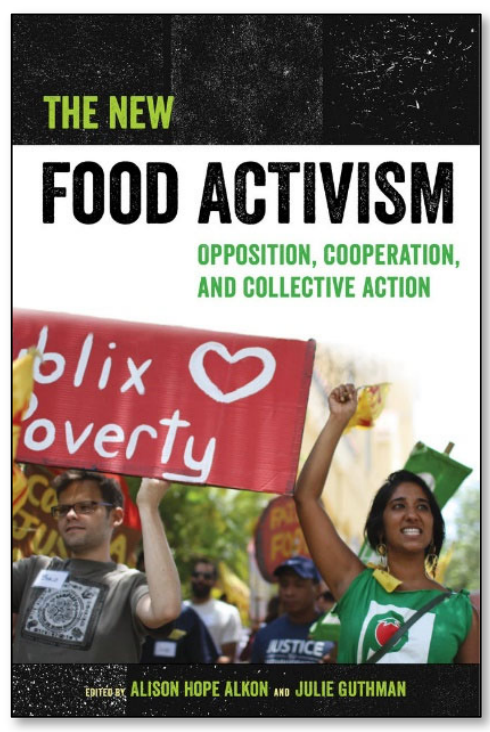

Submitted December 17, 2018 / Published online April 30, 2019

Citation: Hasanov, M. (2019). All roads lead to The New Food Activism [Book review].

Journal of Agriculture, Food Systems, and Community Development, 9(1), 123-125.

https://doi.org/10.5304/jafscd.2019.091.002

Copyright (C) 2019 by the Author. Published by the Lyson Center for Civic Agriculture and Food Systems. Open access under CC-BY license.

T he New Food Activism: Opposition, Cooperation, and Collective Action reminds us that understanding food activism in the world of alternative facts and post-truth politics requires breaking off with commonly established norms, criticisms, and controversies. With an awareness that there are connotations associated with "food justice" and "neoliberalism" that are quintessential in discussing food matters, Alison Hope Alkon and Julie Guthman propose that food activism is fertile

* Mustafa Hasanov is a Ph.D. candidate at the University of Groningen, the Netherlands. His research focuses on local collective action within local energy and food sharing initiatives. He is currently undertaking research on the role of community self-organization in the delivery of sustainable, resilient, and socially just developments in food systems. He is the online officer of the Royal Geographical Society (with IBG) Food Geographies Working Group. He can be reached at Faculty of Spatial Sciences, Department of Planning, University of Groningen, Landleven 1, 9747 AD Groningen, The Netherlands, or m.h.hasanov@,rug.nl. ground for the growth of reflexive, innovative, and immersive food politics. Departing from the view that alternative food systems have been described as apolitical and short-sighted, this edited volume suggests that food activism embodies politics and strategic action. This new sort of food activism seeks to build alliances and coalitions that go beyond the current notion of alternatives in describing transformative changes in food systems. The book is divided into three parts, each unpacking different possibilities for the role of activism in reshaping food systems.

The chapters in Part One, "Regulatory Campaigns," follow and outline a notion on food activism in industrial agriculture. While some might argue that influencing industrial agriculture is far beyond the power of the "foodies," Jill Lindsey Harrison (Chapter 2) follows the pesticide regulatory reform activism in California. The chapter details two archetypes of anti-pesticide activism: sustainable agriculture and drift activism. Both 
forms of activism take different stances on public health, which seem to be underrepresented in sustainable agriculture regulatory reforms. Similarly, Emily Eaton (Chapter 3) discusses another controversy associated with inessive farming: genetically modified crops. Eaton outlines collective opposition strategies to genetically modified crops in Canada. The chapter suggests that a neoliberal outlook on collective action often does not take into account how producers, who act individually, can build coalitions and alliances that forge social and institutional support for a common good.

While people often associate local activism in food and agriculture domain with strong radical protests and perhaps grievances, Julie Guthman and Sandy Brown (Chapter 4) depict a rather unusual type of food activism-one that takes place in courts, instead of out in the streets. The chapter follows a trial on the potential use of methyl iodide, a chemical agent proposed for use as a fungicide and pesticide in California. Although the case was dismissed due to moot motion, the activists won because they were underestimated by their opponents, used clever tactics, and perhaps had a bit of luck.

Part Two, "Working for Workers," discusses issues of labor and food justice within food systems. Joshua Sbicca (Chapter 5) suggests that the notion of food justice in food systems needs to incorporate matters of labor and economic inequality. It is only by doing this that we can build laborfood justice alliances that will transform food politics. These alliances rely on confrontational labor campaigns, increasing the visibility of workers, address inequalities in class-conscious politics and create socially just food systems. Using examples of workplace justice campaigns on the local, regional, and national levels, Joann Lo and Biko Koenig (Chapter 6) emphasize the importance of the laborer in the creation of a sustainable food industry. The chapter outlines three strategies of solidarity with food laborers: (1) consumer support without boycotting products, (2) institutional activism that underpins labor standards, (3) and chain-of-command activism that supports fair labor conditions.

Analyzing consumer-based initiatives aimed at creating fair working conditions, Laura-Anne
Minkoff-Zern (Chapter 7) proposes that placing the food worker in the center of transforming food systems will lead to improved labor conditions, provide just food, and ensure farmworker-led and consumer-supported change.

The third part of the volume, titled "Collective Practices," focuses on the impact of various collective practices in transforming food systems. In Chapter 8, Andrew Zitcer scrutinizes the homogeneity within the member base of co-ops and cautions that co-ops can easily slip into becoming spaces of exclusion. Nevertheless, consumer cooperatives are depicted as places of collective action, democratic practices, and community control. Developing this discussion of homogeneity, Meleiza Figueroa and Alison Hope Alkon (Chapter 9) attempt to break the association between eliteness and alternative food movement by analyzing initiatives in marginalized neighborhoods. They illustrate that the presence of alternative food hubs in working-class neighborhoods seems to be associated with three features: affordability, community building, and cooperative practices_-all of which highlight the importance of collective performances and collective resistance. Expanding on this topic, Michelle Glowa (Chapter 10) looks into activism within urban agriculture initiatives. Glowa argues that urban agriculture is not merely about food access in urban areas, but also has implications for redefining property rights and the right to garden. The chapter points out that activism within urban agriculture projects can challenge property developers and rebuild the connection between markets, society, and individuals regarding land use.

Applying urban political ecology and solidarity economy lenses, Penn Loh and Julian Agyeman (Chapter 11) unpack the notion of a food solidarity economy as a conceptual vehicle that can explain the collective impact of food justice initiatives by incorporating issues of class, gender, and race. Hence, a food solidarity economy illustrates one possible way of breaking the ideological constraints of neoliberalism. Next, Tanya M. Kersen and Zoe W. Brent (Chapter 12) remind us that the debate on food systems and food politics often underestimates issues of land history and resource struggle. The authors propose that land, and 
particularly, land justice, can be used as unifying elements in the ambiguities between resisting neoliberal land use practices and could justify the battles which the activists could wage against the system.

In the concluding chapter, Hope Alkon and Guthman draw parallels between movements, such as Occupy Wall Street and Black Lives Matter, and emerging forms of (new) food activism. This is a subtle reminder to the reader that food activism carries a set of subjectivities, where food is the anchor point that brings people and action together. The edited volume provides a varied reading on collective action, opposition, and cooperation within food systems. The chapters are written in a manner that makes the information accessible to general, knowledgable, and expert audiences. Hence, the book is a valuable edition for scholars, practitioners, activists, and others interested in the latest developments in food systems. The New Food Activism illustrates that food activism is not fixed in space and time. Rather, it is a spectrum, and understanding this spectrum better will help us to sustain the growth of a new food tradition that honors progressive food systems and society more broadly. 